\title{
Does anterolateral ligament internal bracing improve the outcomes of anterior cruciate ligament reconstruction in patients with generalized joint hypermobility?
}

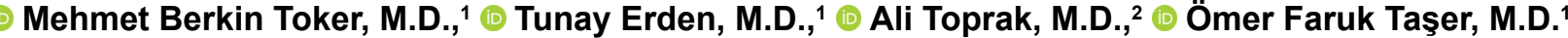

${ }^{1}$ Department of Orthopaedics and Traumatology, Acıbadem Fulya Hospital Sports Medicine Center, İstanbul-Turkey

2Department of Biostatistics and Medical Informatics, Bezmialem Vakıf University Faculty of Medicine, İstanbul-Turkey

\begin{abstract}
BACKGROUND: Generalized joint hypermobility $(\mathrm{GJH})$ is a risk factor for anterior cruciate ligament $(A C L)$ injury and $A C L$ graft failure and is considered an indication for anterolateral ligament (ALL) reconstruction. The aim of this retrospective study was to compare functional outcomes, rupture rates, and residual instability in patients with $\mathrm{GJH}$ undergoing isolated $A C L$ reconstruction or combined $A C L$ reconstruction and ALL augmentation with internal bracing (ALL-IB).
\end{abstract}

METHODS: Sixty-eight patients with GJH and unilateral ACL injury were randomly assigned to undergo either isolated $A C L$ reconstruction (Group I) or combined ACL reconstruction and ALL-IB (Group 2). The patients were evaluated pre- and postoperatively; their medical histories; physical examination results; anterior knee translation, as measured using the KT-1000 arthrometer; and scores of validated knee assessments were recorded.

RESULTS: Groups I and 2 consisted of 37 and 31 patients, respectively. The mean follow-up was $30.1 \pm 4$. I and 28 . I \pm 2.9 months, respectively. In the final evaluation, the patients in Group 2 showed better rotational stability, as evaluated by the pivot-shift test $(p=0.013)$; better anteroposterior stability, as evaluated by KT- I000 arthrometry $(p=0.00 \mathrm{I})$; similar function $(p=0.14$ for the Lysholm, $p=0.1 \mathrm{I}$ for the Cincinnati, and $p=0.19$ for the International Knee Documentation Committee subjective score); and failure rate $(p=0.4 \mathrm{I})$.

CONCLUSION: The functional outcomes were similar between the groups. The stability outcomes after combined ACL and ALLIB were better than those after isolated $A C L$ reconstruction in patients with $\mathrm{GJH}$. However, the technique and its results need to be validated in larger patient series and prospective randomized controlled trials.

Keywords: Anterior cruciate ligament reconstruction; anterolateral ligament; augmentation; internal brace; knee instability; suture tape.

\section{INTRODUCTION}

Numerous factors affect the outcomes of anterior cruciate ligament $(A C L)$ reconstruction; approximately $65 \%$ of patients undergoing $A C L$ reconstruction return to pre-injury sports levels, and at least $10.3 \%$ experience graft failure within 10 years. ${ }^{[1]}$ Considering of these poor functional results and high failure rates, there is renewed interest in the role of the anterolateral structures of the knee which controls the rotatory stability, and their load-sharing properties in conjunction with ACL grafts. ${ }^{[2,3]}$
The anterolateral ligament ( $A L L$ ) has been identified as a supporter to the anterolateral rotational stability of the knee joint, and it has a strong association with ACL ruptures. ${ }^{[4-6]}$ Ferretti et al. ${ }^{[7]}$ reported that approximately $90 \%$ of ALL injuries are associated with $A C L$ tears, and due to this strong relationship, recent studies have focused on clearly demonstrating the biomechanical and anatomical features of the ALL. In a recent biomechanical study, Nitri et al. ${ }^{[8]}$ reported that concurrent $A C L$ reconstruction and ALL reconstruction significantly improve the rotatory stability of the knee compared with ACL reconstruction only.

Cite this article as: Toker MB, Erden T, Toprak A, Taşer ÖF. Does anterolateral ligament internal bracing improve the outcomes of anterior cruciate ligament reconstruction in patients with generalized joint hypermobility?. Ulus Travma Acil Cerrahi Derg 2022;28:320-327.

Address for correspondence: Tunay Erden, M.D.

Acıbadem Fulya Hastanesi Sporcu Sağlığı Merkezi, Ortopedi ve Travmatoloji Bölümü, İstanbul, Turkey

Tel: +90 212 - 26I 4242 E-mail: tunayerden@gmail.com

Ulus Travma Acil Cerrahi Derg 2022;28(3):320-327 DOI: 10.14744/tjtes.2021.39998 Submitted: 23.09.202I Accepted: 28.12.2021

Copyright 2022 Turkish Association of Trauma and Emergency Surgery 
Generalized joint hypermobility $(\mathrm{GJH})$ is characterized by joint laxity due to abnormal soft tissue structures and has been shown to be a risk factor for ACL injury and ACL graft failure. ${ }^{[9-13]} \mathrm{GJH}$ has been described as an indication for $A L L$ reconstruction. ${ }^{[14,15]}$

The aim of this retrospective study was to compare functional outcomes, rupture rates, and residual instability in patients with $\mathrm{GJH}$ undergoing isolated $\mathrm{ACL}$ reconstruction or combined $A C L$ reconstruction and $A L L$ internal bracing (ALL-IB). The hypothesis of the study was that combined $A C L$ reconstruction and ALL-IB will exhibit better outcomes than isolated $A C L$ reconstruction with hamstring tendons.

\section{MATERIALS AND METHODS}

The patients (Group 2) who underwent unilateral isolated $A C L$ reconstruction or combined $A C L$ reconstruction and ALL-IB by a senior surgeon between 2015 and 2019 were followed prospectively and outcomes retrospectively analyzed.

The inclusion criteria included patients with hypermobility, as confirmed by the modified Beighton-Horan criteria using a point scoring system, ${ }^{[16]}$ and the contralateral limb was evaluated to exclude any possible effects of trauma on the injured extremity. A minimum value of 5 of 8 was established as the criterion for hypermobility for our study because we exclude the injured side from the Beighton scale evaluation (Table I). The examination was performed by the senior author using the Beighton scale.

The inclusion criteria additionally included patients who presented to the senior author with an acute or chronic ACL rupture, were older than 18 years, underwent primary single-bundle $A C L$ reconstruction, had an isolated $A C L$ injury without a concomitant ligament injury, had normal alignment of the lower extremities, and were followed for a minimum duration of 2 years.

The exclusion criteria included patients who underwent concomitant subtotal or total meniscectomy $(n=1)$; underwent meniscal repair $(n=9)$; sustained other ligament injuries require additional surgery $(n=6)$; had a chondral lesion of an Outerbridge Grade II or higher, as assessed by arthroscopy $(n=4)$; previously underwent ipsilateral or contralateral knee surgery $(n=3), A C L$ reconstruction with bone-patellar tendon-bone autograft $(n=3)$, or allograft $(n=2)$. Considering the criteria, a total of 68 patients were included in the study.

The patients were randomly selected and the patients admitted to the hospital in the $I^{\text {st }}$ and $3^{\text {rd }}$ weeks of each month were included in Group I, and those in the $2^{\text {nd }}$ and $4^{\text {th }}$ weeks were included in Group 2.

According to the criteria, all patients were divided into two groups: Group I, consisting of $A C L$ reconstruction patients with GJH treated with a hamstring autograft; Group 2, consisting of $A C L$ reconstruction patients with $\mathrm{GJH}$ treated with a hamstring autograft and ALL-IB. After the patients were grouped according to the criteria listed above, autologous hamstring grafts were selected to be used for all of the patients in the two groups. Group I consisted of 37 patients, and Group 2 consisted of 31 patients (Table 2).

\section{ALL-IB Surgical Technique}

All operations were performed by a single experienced senior surgeon in a sport surgery clinic. Each patient was placed in a standard supine position for arthroscopy with a tourniquet on the upper thigh. Semitendinosus and gracilis tendon grafts were harvested using traditional surgical incisions. After diagnostic arthroscopy, partial meniscectomy and chondral debridement were performed in some cases before $A C L$ reconstruction, and $A C L$ remnants were removed. The tunnel was placed in accordance with the single-bundle $A C L$ reconstruction technique. ALL-IB was performed after $A C L$ reconstruction was completed in the same session.

The lateral femoral epicondyle, Gerdy tubercle, and outermost of the fibular head were palpated and marked ${ }^{[17,18]}$ (Fig. la). The tibial insertion was marked halfway between the Gerdy tubercle and the outermost point of the fibular head, about $10 \mathrm{~mm}$ distal to the tibiofemoral joint. ${ }^{[18]}$

Table I. Beighton and Horan criteria for generalized joint hypermobility

\begin{tabular}{|c|c|c|c|}
\hline & \multirow[t]{2}{*}{ Unable to perform } & \multicolumn{2}{|c|}{ Able to perform } \\
\hline & & Right & Left \\
\hline I. Oppose the thump to the volar aspect of the forearm & 0 & $\mathrm{I}$ & 1 \\
\hline 2. Passively extension of the fifth finger beyond 900 & 0 & 1 & I \\
\hline 3. Hyperextend the knee to $>100$ & 0 & 1 & 1 \\
\hline 4. Hyperextend the elbow to $>100$ & 0 & 1 & 1 \\
\hline 5. Place hands flat on the floor without bending the knees & 0 & 1 & I \\
\hline
\end{tabular}

Generalized joint hypermobility was defined as a total score of $\geq 5$ points for the present study. 
Table 2. Demographic characteristics and additional diagnosis of groups

\begin{tabular}{|c|c|c|c|}
\hline Variable & Group I (Isolated ACL) $n=37$ & Group $2(A C L+A L L) n=3 I$ & p-value \\
\hline Age (years) & $30.1 \pm 4.1$ & $28.1 \pm 2.9$ & n.s \\
\hline \multicolumn{4}{|l|}{ Gender, n (\%) } \\
\hline Female & II (29.7) & $16(51.6)$ & n.s \\
\hline Male & $26(70.3)$ & $15(48.4)$ & \\
\hline \multicolumn{4}{|l|}{ Side, n (\%) } \\
\hline Right & $22(59.4)$ & $19(61.3)$ & \\
\hline Left & $15(40.6)$ & $13(38.7)$ & n.s \\
\hline Duration of injury before surgery (mo) & $1.6 \pm 0.4$ & $1.4 \pm 0.7$ & n.s \\
\hline Follow-up time (mo) & $26.7 \pm 4.1$ & $33.2 \pm 5.0$ & n.s \\
\hline Partial meniscectomy, n (\%) & $7(18.9)$ & $5(16.1)$ & n.s \\
\hline Chondral pathology (grade I-2), n (\%) & $5(13.5)$ & $6(19.3)$ & n.s \\
\hline Contralateral $\mathrm{ACL}$ rupture, $\mathrm{n}(\%)$ & $3(8.1)$ & $2(6.4)$ & n.s \\
\hline Graft size $(\mathrm{mm})$ & $8.1 \pm 0.6$ & $8.4 \pm 0.4$ & n.s \\
\hline Graft rupture, n (\%) & $4(10.8)$ & I (3.2) & n.s \\
\hline
\end{tabular}

ACL: Anterior cruciate ligament; ALL: Anterolateral ligament.

IB (suture tape augmentation) was performed with ultrahigh-strength 2-mm-wide tape (FiberTape, Arthrex, Naples, $\mathrm{FL}$ ) and 2 bone anchors (SwiveLock, Arthrex, Naples, FL). A 2-cm vertical incision was made starting over the lateral femoral epicondyle in the posterior and proximal directions. The iliotibial band was split, and 2.4-mm K-wire was placed at the anatomic femoral insertion of the ALL (Fig. Ib). It was checked arthroscopically that there is no contact with $A C L$ femoral tunnel. Then, the skin was incised horizontally at the previous marked location for ALL tibial insertion, and the second 2.4-mm K-wire was placed at the anatomic tibial insertion of the ALL (Fig. Ib). A hemostat was directed distally under the iliotibial band, superficial to the lateral collateral ligament. The hemostat was distally moved sideways to create a tunnel for the FiberTape and break any adhesions (Fig.
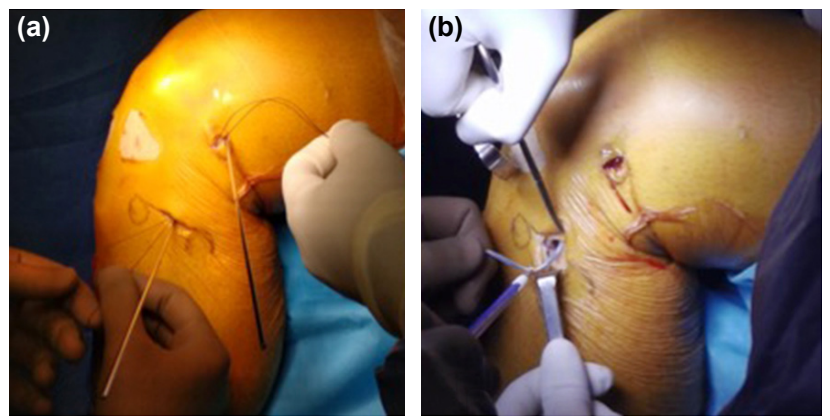

Figure 1. (a) GT: Gerdy tubercle, LFE: Lateral femoral epicondyle, $\mathrm{FH}$ : Fibular head. (b) The first 2.4-mm K-wire is placed at the anatomic femoral insertion of the anterolateral ligament (ALL), just proximal and posterior to the lateral femoral epicondyle. The second 2.4-mm K-wire is inserted at the tibial insertion of the ALL, midway between the Gerdy tubercle and the fibular head. The hemostat was distally moved sideways to create a tunnel for the FiberTape to break any adhesions.
Ib). To measure whether the isometric points are correct a looped suture (vycril) is wrapped around $2 \mathrm{~K}$ wires and knee ROM is observed. In accordance with ALL biomechanics it is expected to be loose in $90^{\circ}$ flexion and tight in extension ${ }^{[19]}$ (Fig. 2a). After predrilling was performed with a 4.5- $\mathrm{mm}$ drill, tapping was performed, and a 4.75-mm SwiveLock loaded with a No.2 FiberTape was placed in the femoral insertion point. The FiberTape was brought to the tibial incision using a lead suture transported by the hemostat. Subsequently, the 5.5-mm SwiveLock was predrilled and tapped to the ALL insertion location (Fig. 2b). The FiberTape was then assessed during movements between $0^{\circ}$ and $90^{\circ}$ of flexion to ensure the tension was not excessively high. Tibial fixation was performed in neutral rotation and nearly full extension.

The same post-operative rehabilitation protocol was used for all patients included in the present study. Immediate full
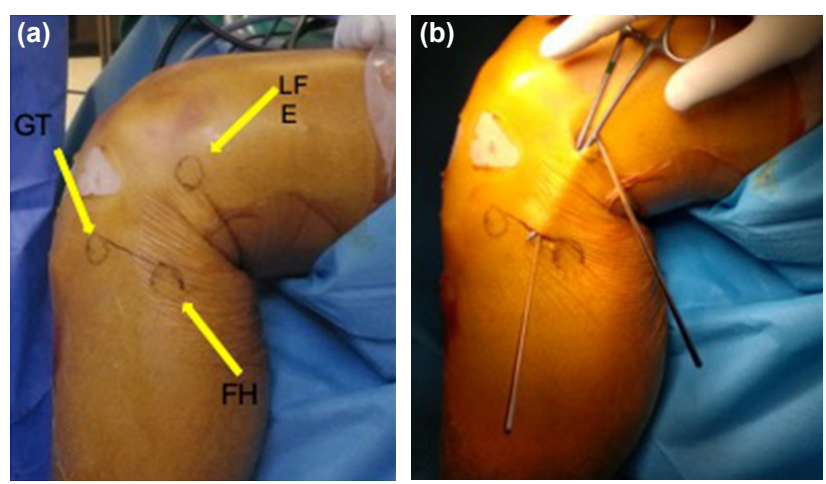

Figure 2. (a) For measurements of the isometric points, a suture was looped around the K-wires to assess the tension during movements through the range of motion. (b) The 5.5-mm diameter Swivelock anchor is fixed on the tibial side. 
weight bearing without a brace was permitted, and closed kinetic chain exercises were started on postoperative day I. After quadriceps muscle control was achieved, the use of crutches was discontinued. A gradual return to sport activities was allowed starting at 6 months for noncontact sports involving pivoting, and at 9 months for contact sports involving pivoting if the results of the isokinetic test were favorable. The follow-ups were performed at 2, 6, 12, and 24 weeks and at I year. Patients who have no complaints after I year were routinely asked to attend a clinical follow-up examination once a year.

The demographic data and additional parameters of the two groups were compared (Table 2).

\section{Clinical Assessments}

Clinical examinations were performed preoperatively and within 2 years postoperatively. All physical examinations were performed by the senior author. The Lachman test and pivot-shift test were used to evaluate knee stability. The results of the Lachman test were graded using a scale of $0(<3 \mathrm{~mm})$, I ( $\geq 3$ and $<5 \mathrm{~mm}), 2$ ( $\geq 5$ and $<10 \mathrm{~mm})$, or $3(\geq 10 \mathrm{~mm})$, and the pivot-shift test results were graded using a scale of 0 (normal), I (subluxation), 2 (jump), or 3 (transient lock). To evaluate anterior stability, the KT-I000 arthrometer (MEDmetric, San Diego, California) was used with the knee in $30^{\circ}$ of flexion and a force of I34 N applied to the knee.

Pre-operative and post-operative functional evaluations were conducted using the International Knee Documentation Committee (IKDC) subjective scale, IKDC objective scale, and the Cincinnati and Lysholm knee scoring scales.

New ruptures were assessed on the basis of clinical graft failure criteria (in a physical examination, the identification of hypermobility with no clear or soft end point in the Lachman and Anterior drawer tests [at least $2+/ 3+$ ] or pivot-shift positivity [at least $2+/ 3+$ ] associated with instability complaints) and the identification of a new graft rupture in magnetic resonance imaging scans. ${ }^{[20]}$

Informed consent was obtained from all patients, and the study was approved by the ethics committee of our institution (IRB no: 2020-06/23).

\section{Statistical Analysis}

The statistical analyses were performed using SPSS, version 22 (IBM SPSS Statistics for Windows, Armonk, NY; IBM Corp., Released 2013). First, a Kolmogorov-Smirnov test was used to determine which variables should be included in the data analysis and whether the data for the variables were normally distributed. Since the data are not normally distributed non-parametric tests were used. The Mann-Whitney $U$ test was used to compare continuous variables across the groups. The Chi-square test and Fisher's exact test were used to compare categorical variables between two groups. The median (QI [ [ ${ }^{\text {st }}$ quartile]-Q3 [3 ${ }^{\text {rd }}$ quartile]), mean \pm standard deviation, frequency, and percentage were reported as descriptive statistics. No sample size estimations were performed because all patients in our hospital database who met the inclusion criteria were analyzed. The statistical significance level was set to $\mathrm{p}<0.05$.

\section{RESULTS}

A total of 68 patients ( $n=37$ for Group I and $n=3$ I for Group 2) with $\mathrm{GJH}$ were followed for a minimum of 2 years. The groups did not differ with respect to age $(p=0.75 \mathrm{I})$, sex $(p=0.843)$, the injured side $(p=0.742)$, the time from injury to surgery $(p=0.50 \mathrm{I})$, the post-operative follow-up time $(p=0.527)$, the intra-articular ACL graft size $(p=0.837)$, the modified Beighton score $(p=0.658)$, or the pre-operative physical examination results $(p=0.59 \mathrm{I}$ for the KT-1000 device, $p=0.294$ for the Lysholm score, $p=0.673$ for the Cincinnati score, $p=0.124$ for the IKDC subjective score, $p=0.445$ for the IKDC objective value, and $p=0.912$ for the pivot-shift test) (Tables I-3).

The patients in Group 2 showed better post-operative clinical anteroposterior stability, which is evaluated by KT-1000 arthrometry $(p<0.00 \mathrm{I})$; better rotational stability, which is evaluated by the pivot-shift test $(p=0.008)$ (Table 4$)$. In Group I, $43.2 \%$ of the patients presented a positive pivot-shift $(35.1 \%$ Grade I, 5.4\% Grade 2, and 2.7\% Grade 3), whereas $12.9 \%$ of the patients in Group 2 showed this result (all grade I). Group 2 had a lower graft failure rate in the final evaluation; however, it did not have statistical significance $(p=0.4 \mathrm{l})$ (Table 4). The clinical evaluations of the post-operative functional outcomes did not show any significant differences between the two groups (Table 4).

There was no significant difference between the groups in terms of the proportions of patients who underwent partial meniscectomy $(p=0.863)$, had different graft sizes $(p=0.83 I)$, had a chondral pathology $(p=0.883)$, and had a contralateral ACL rupture $(p=0.894)$ (Table 2$)$.

No complications, such as infection, loss of range of motion, or cyclops syndrome, were observed. Three (8.8\%) patients in Group 2 had lateral discomfort in the $1^{\text {st }}$ month after surgery, and discomfort continued for up to 3 months; however, no problem was observed in the rehabilitation of any of these patients.

\section{DISCUSSION}

The final results of the study supported our hypothesis; the stability outcomes after combined $A C L$ reconstruction and ALL-IB were better than those after isolated $A C L$ reconstruction in patients with $\mathrm{GJ} H$. However, functional outcomes were similar between the groups. 
Table 3. Comparison of preoperative outcomes among the groups

\begin{tabular}{|c|c|c|c|}
\hline Variable & Group I (GJH) n=37 & Group $2(G J H+A L L) n=3 I$ & p-value \\
\hline Preoperative SSD (mm) & $8.1 \pm 1.8$ & $8.0 \pm 2.3$ & n.s \\
\hline \multicolumn{4}{|l|}{ Lachman test, n (\%) } \\
\hline I & $5(13.5)$ & $6(19.3)$ & n.s \\
\hline II & $24(64.9)$ & $19(61.3)$ & \\
\hline III & $8(21.6)$ & $6(19.3)$ & \\
\hline \multicolumn{4}{|l|}{ Pivot-shift test, n (\%) } \\
\hline 1 & $7(18.9)$ & $9(29)$ & n.s \\
\hline II & $24(64.9)$ & $17(54.8)$ & \\
\hline III & $6(16.2)$ & $5(16.1)$ & \\
\hline \multicolumn{4}{|l|}{ Lysholm Knee Score $^{a}$} \\
\hline Mean $\pm S D$ & $73.5 \pm 5.8$ & $72.3 \pm 6.1$ & n.s \\
\hline Median (QI-Q3) & $74(67.5-78)$ & $72(69-77)$ & \\
\hline \multicolumn{4}{|l|}{ Cincinnati knee score ${ }^{a}$} \\
\hline Mean $\pm S D$ & $53.8 \pm 6.1$ & $53.7 \pm 4.9$ & n.s \\
\hline Median (QI-Q3) & $54(50-59)$ & $52(5 I-58.5)$ & \\
\hline \multicolumn{4}{|l|}{ IKDC subjective score ${ }^{a}$} \\
\hline Mean $\pm S D$ & $56.1 \pm 3.1$ & $56.8 \pm 5.3$ & n.s \\
\hline Median (QI-Q3) & $57.3(55.7-56.3)$ & $56.9(53.3-60.4)$ & \\
\hline \multicolumn{4}{|c|}{ IKDC objective grade, $\mathrm{n}(\%)$} \\
\hline A & $0(0)$ & $0(0)$ & n.s \\
\hline B & $3(8.1)$ & $3(9.7)$ & \\
\hline C & $25(67.5)$ & $19(61.3)$ & \\
\hline$D$ & $9(27.0)$ & $9(29.0)$ & \\
\hline
\end{tabular}

aThe values that had significant differences are given as the means \pm standard deviations and medians (QI [I ${ }^{\text {st }}$ quartile]-Q3 [3 ${ }^{\text {rd }}$ quartile]). G]H: Generalized joint hypermobility; ALL: Anterolateral ligament; SSD: Side to side difference; SD: Standard deviation; IKDC: International Knee Documentation Committee.

A lack of stabilizing structures surrounding the knee is considered to lead to poor outcomes of ACL reconstruction in patients with $\mathrm{GJH} .{ }^{[21]}$ Recent studies have suggested that patients with $\mathrm{GJH}$ have an increased risk for $A C L$ rupture and graft failure and commonly use poor jump landing strategies. ${ }^{[10-12]}$ Another multicenter study showed that knee recurvatum by more than $5^{\circ}$ is a significant independent predictor of $A C L$ graft failure. ${ }^{[22]}$ Vaishya and Hasija reported that joint hypermobility is more common in patients with $A C L$ injury than in control groups. ${ }^{[23]}$ In a prospective study of 1558 athletes, Myer et al. ${ }^{\left[{ }^{I I}\right]}$ reported that the presence of knee hyperextension beyond neutral resulted in a five-fold higher risk of $A C L$ injury, taking into account the GJH measurements. The authors hypothesized that this level of hyperextension might correlate with poor jump landing mechanics. Magnussen et al. ${ }^{[2]}$ reported that ligamentous hypermobility is associated with poorer Lachman, anterior drawer, and pivot-shift test results in individuals with $A C L$ injury. Sundemo et al. ${ }^{[25]}$ reported that patients with knee recurvatum had more anteriorposterior instability both pre-operative and post-operative periods. Kim et al. ${ }^{[2]]}$ performed a study to evaluate whether laxity of the uninjured knee influences the outcomes after $\mathrm{ACL}$ reconstruction. The authors divided $163 \mathrm{ACL}$ reconstruction cases into three groups based on KT-1000 manual maximum measurements of the contralateral normal knee ( $<5 \mathrm{~mm}, 5-7.5 \mathrm{~mm}$, and $>7.5 \mathrm{~mm}$ ) and reported that patients with $>7.5 \mathrm{~mm}$ of translation in the contralateral knee had greater anterior knee laxity and inferior Lysholm and IKDC scores than did the other two groups. Another study by the same group showed that a higher hypermobility index corresponded to greater residual post-operative instability and lower Lysholm and IKDC functional scores.. ${ }^{[10]}$ A study by Larson et al. ${ }^{[26]}$ showed that patients with hypermobility had a failure rate of $25 \%$ for the hamstring graft.

The previous studies reported that $\mathrm{GJH}$ or genu recurvatum are possible indications for a combined lateral extra-articular procedure through anatomical reconstruction of the ALL, with the goal of improving ACL graft stability, and functional scores. ${ }^{[14,27]}$ To date, several techniques for anatomical ALL reconstruction have been described, but many of these techniques use a hamstring tendon autograft or allograft. ${ }^{[3]}$ With 
ALL-IB, a tendon graft is not required; the native ligament is repaired in acute cases and retensioned in cases of a chronic ALL rupture. ${ }^{[17,18]}$ The ALL-IB technique is a simple, minimally invasive, and quick procedure that provides additional anterolateral rotational stability and is often performed together with $A C L$ reconstruction. ${ }^{[17,18]}$ This technique encourages natural healing of the ALL and in chronic cases, and the natural tension in the ALL can be restored by tensioning the ALL. [17,18] The tape reinforces the ligament as a secondary stabilizer, encouraging natural healing of the ligament by protecting it during the healing phase and promoting early mobilization. [18] Helito et al. ${ }^{[20]}$ compared functional outcomes, residual instability, and rupture rates in patients with ligamentous hypermobility undergoing isolated $A C L$ reconstruction or combined $A C L$ and $A L L$ reconstruction. They reported that combined $A C L$ and $A L L$ reconstruction in patients with ligamentous hypermobility resulted in a lower failure rate and better knee stability parameters than did isolated ACL reconstruction and no differences were found in the functional scores. Kim et al. ${ }^{[2]}$ showed a positive pivot-shift test rate of 38. I\% and significantly lower functional scores (IKDC and Lysholm) for patients with $\mathrm{GJH}$ than for patients without $\mathrm{GJH}$. Vadala et al. ${ }^{[28]}$ showed a positive pivot-shift rate of $57.1 \%$ in female athletes with joint hypermobility. For combined ALL-IB plus ACL reconstruction, our study demonstrated a re-rupture rate of only $3.2 \%$ ( $I$ of $3 \mathrm{I}$ ), a rate of residual laxity in the pivot-shift test of $12.9 \%$ (4 of $3 \mathrm{I}$ ) and similar functional scores in this high-risk population. ${ }^{[21,28]}$

The present study has various limitations. This was a retrospective study, reconstructions with the other types of grafts (patellar tendon and allograft) were not evaluated in this study, and the results are limited to short-/mid-term results; therefore, complications such as excessive strain in the lateral

Table 4. Comparison of postoperative outcomes among the groups

\begin{tabular}{|c|c|c|c|}
\hline Variable & Group I (GJH) n=37 & Group $2(G J H+A L L) n=3 I$ & p-value \\
\hline \multicolumn{4}{|c|}{ Postoperative KT-I000 (mm) } \\
\hline Mean $\pm S D$ & $3.4 \pm 0.7$ & $2.2 \pm 1.0$ & 0.01 \\
\hline Median (QI-Q3) & $3(3-4)$ & $2(1.5-3)$ & \\
\hline \multicolumn{4}{|l|}{ Lachman test, n (\%) } \\
\hline 0 & $23(62.2)$ & $23(74.1)$ & 0.46 \\
\hline I & $10(27.0)$ & $7(22.6)$ & \\
\hline II & $3(8.1)$ & I (3.2) & \\
\hline III & I (2.7) & $0(0)$ & \\
\hline \multicolumn{4}{|l|}{ Pivot-shift test, n (\%) } \\
\hline 0 & $21(56.8)$ & $28(90.3)$ & 0.02 \\
\hline I & $13(35.1)$ & $3(9.7)$ & \\
\hline II & $2(5.4)$ & $0(0)$ & \\
\hline III & I (2.7) & $0(0)$ & \\
\hline \multicolumn{4}{|l|}{ Lysholm Knee Scorea } \\
\hline Mean $\pm S D$ & $86.3 \pm 4.7$ & $89.3 \pm 5.2$ & 0.14 \\
\hline Median (QI-Q3) & $87.0(82-89)$ & $90.0(88.5-93)$ & \\
\hline \multicolumn{4}{|l|}{ Cincinnati Knee Score $^{a}$} \\
\hline Mean $\pm S D$ & $86.5 \pm 4.9$ & $90.7 \pm 4.1$ & 0.11 \\
\hline Median (QI-Q3) & $89.0(82-93.2)$ & $92(88-93.2)$ & \\
\hline \multicolumn{4}{|l|}{ IKDC subjective score ${ }^{a}$} \\
\hline Mean $\pm S D$ & $86.2 \pm 7.0$ & $89.6 \pm 3.5$ & 0.19 \\
\hline Median (QI-Q3) & $86.2(82.2-92.5)$ & $88.5(86.2-93.4)$ & \\
\hline \multicolumn{4}{|c|}{ IKDC objective grade, $\mathrm{n}(\%)$} \\
\hline A & $26(70.3)$ & $24(77.4)$ & 0.08 \\
\hline B & $9(24.3)$ & $6(19.4)$ & \\
\hline C & $2(5.4)$ & I (3.2) & \\
\hline$D$ & $0(0)$ & $0(0)$ & \\
\hline
\end{tabular}

${ }^{a}$ The values that had significant differences are given as the means \pm standard deviations and medians ( $\mathrm{Q}$ I [ I ${ }^{\text {st }}$ quartile]-Q3 [3 ${ }^{\text {rd }}$ quartile]). GJH: Generalized joint hypermobility; ALL: Anterolateral ligament; SD: Standard deviation; IKDC: International Knee Documentation Committee. 
compartment and osteoarthritis could not be detected in this time period. Only FiberTape was used for ALL reconstruction, and no objective measurements of the rotational laxity were performed. A single surgeon experience shared and all clinical examinations were performed by the same surgeon.

\section{Conclusion}

For patients with $\mathrm{GJH}$, compared with isolated $A C L$ reconstruction, combined $A C L$ reconstruction and $A L L-I B$ reduces the likelihood of failure, improves anteroposterior, and rotation stability. However, the technique and its results need to be validated in larger patient series and prospective randomized controlled trials. We recommend performing this technique routinely for patients with hypermobility who undergo $A C L$ reconstruction. However, the technique and its results need to be validated in larger patient series and prospective randomized controlled trials.

Ethics Committee Approval: This study was approved by the Acibadem University Faculty of Medicine Ethics Committee (Date: 30.04.2020, Decision No: 2020-06/23).

Peer-review: Internally peer-reviewed.

Authorship Contributions: Concept: T.E.; Design: T.E., Ö.F.T.; Supervision: M.B.T., T.E.; Resource: M.B.T., T.E., Ö.F.T., A.T.; Materials: Ö.F.T., T.E.; Data: M.B.T., T.E.; Analysis: A.T.; Literature search: M.B.T., T.E., M.B.T.; Writing: T.E., M.B.T.; Critical revision: Ö.F.T., T.E., M.B.T.

Conflict of Interest: None declared.

Financial Disclosure: The authors declared that this study has received no financial support.

\section{REFERENCES}

1. Anderson MJ, Browning WM 3rd, Urband CE, Kluczynski MA, Bisson LJ. A systematic summary of systematic reviews on the topic of the anterior cruciate ligament. Orthop J Sports Med 2016;4:2325967116634074.

2. Claes S, Vereecke E, Maes M, Victor J, Verdonk P, Bellemans J. Anatomy of the anterolateral ligament of the knee.J Anat 2013;223:321-8. [CrossRef]

3. Roessler PP, Schuttler KF, Heyse TJ, Wirtz DC, Efe T. The anterolateral ligament (ALL) and its role in rotational extra-articular stability of the knee joint: A review of anatomy and surgical concepts. Arch Orthop Trauma Surg 2016;136:305-13. [CrossRef]

4. Parsons EM, Gee AO, Spiekerman C, Cavanagh PR. The biomechanical function of the anterolateral ligament of the knee. Am J Sports Med 2015;43:669-74. [CrossRef]

5. Sonnery-Cottet B, Lutz C, Daggett M, Dalmay F, Freychet B, Niglis L, et al. The involvement of the anterolateral ligament in rotational control of the knee. Am J Sports Med. 2016;44:1209-14. [CrossRef]

6. Van Dyck P, Clockaerts S, Vanhoenacker FM, Lambrecht V, Wouters K, De Smet E, et al. Anterolateral ligament abnormalities in patients with acute anterior cruciate ligament rupture are associated with lateral meniscal and osseous injuries. Eur Radiol 2016;26:3383-91. [CrossRef]

7. Ferretti A, Monaco E, Fabbri M, Maestri B, De Carli A. Prevalence and classification of injuries of anterolateral complex in acute anterior cruciate ligament tears. Arthroscopy 2017;33:147-54. [CrossRef]

8. Nitri M, Rasmussen MT, Williams BT, et al. An in vitro robotic assess- ment of the anterolateral ligament, part 2: Anterolateral ligament reconstruction combined with anterior cruciate ligament reconstruction. Am J Sports Med 2016;44:593-601. [CrossRef]

9. Kim SJ, Chang JH, Kim TW, Jo SB, Oh KS. Anterior cruciate ligament reconstruction with use of a single or double-bundle technique in patients with generalized ligamentous laxity.J Bone Joint Surg Am 2009;91:25762. [CrossRef]

10. Kim SJ, Moon HK, Kim SG, Chun YM, Oh KS. Does severity or specific joint laxity influence clinical outcomes of anterior cruciate ligament reconstruction? Clin Orthop Relat Res 2010;468:1136-41. [CrossRef]

11. Myer GD, Ford KR, Paterno MV, Nick TG, Hewett TE. The effects of generalized joint laxity on risk of anterior cruciate ligament injury in young female athletes. Am J Sports Med 2008;36:1073-80. [CrossRef]

12. Ramesh R, Von Arx O, Azzopardi T, Schranz PJ. The risk of anterior cruciate ligament rupture with generalised joint laxity. J Bone Joint Surg Br 2005;87:800-3. [CrossRef]

13. Uhorchak JM, Scoville CR, Williams GN, Arciero RA, St Pierre P, Taylor DC. Risk factors associated with noncontact injury of the anterior cruciate ligament: A prospective four-year evaluation of 859 West Point cadets. Am J Sports Med 2003;31:831-42. [CrossRef]

14. Getgood A, Brown C, Lording T, Amis A, Claes S, Geeslin A, et al. The anterolateral complex of the knee: Results from the international ALC consensus group meeting. Knee Surg Sports Traumatol Arthrosc 2019;27:166-76. [CrossRef]

15. Sonnery-Cottet B, Thaunat M, Freychet B, Pupim BH, Murphy CG, Claes S. Outcome of a combined anterior cruciate ligament and anterolateral ligament reconstruction technique with a minimum 2-year follow-up. Am J Sports Med 2015;43:1598-605. [CrossRef]

16. Beighton P, Solomon L, Soskolne CL. Articular mobility in an African population. Ann Rheum Dis 1973;32:413-8. [CrossRef]

17. Monaco E, Mazza D, Redler A, Drogo P, Wolf MR, Ferretti A. Anterolateral ligament repair augmented with suture tape in acute anterior cruciate ligament reconstruction. Arthrosc Tech 2019;8:e369-73. [CrossRef]

18. Heusdens CH, Hopper GP, Dossche L, Mackay GM. Anterolateral ligament repair with suture tape augmentation. Arthrosc Tech 2018;7:e1311-4. [CrossRef]

19. Sonnery-Cottet B, Barbosa NC, Tuteja S, Daggett M, Kajetanek C, Thaunat M. Minimally invasive anterolateral ligament reconstruction in the setting of anterior cruciate ligament injury. Arthrosc Tech 2016;5:e211-5. [CrossRef]

20. Helito CP, Sobrado MF, Giglio PN, Bonadio MB, Pécora JR, Camanho $\mathrm{GL}$, et al. Combined reconstruction of the anterolateral ligament in patients with anterior cruciate ligament injury and ligamentous hyperlaxity leads to better clinical stability and a lower failure rate than isolated anterior cruciate ligament reconstruction. Arthroscopy 2019;35:2648-54.

21. Kim SJ, Choi CH, Kim SH, Lee SK, Lee W, Kim T, Jung M. Bone-patellar tendon-bone autograft could be recommended as a superior graft to hamstring autograft for $\mathrm{ACL}$ reconstruction in patients with generalized joint laxity: 2- and 5-year follow-up study. Knee Surg Sports Traumatol Arthrosc 2018;26:2568-79. [CrossRef]

22. Group M, Cooper DE, Dunn WR, Huston LJ, Haas AK, Spindler KP, et al. Physiologic preoperative knee hyperextension is a predictor of failure in an anterior cruciate ligament revision cohort: A report From the MARS group. Am J Sports Med 2018;46:2836-41. [CrossRef]

23. Vaishya R, Hasija R. Joint hypermobility and anterior cruciate ligament injury. J Orthop Surg (Hong Kong) 2013;21:182-4. [CrossRef]

24. Magnussen RA, Reinke EK, Huston LJ, MOON Group; Hewett TE, Spindler KP. Effect of high-grade preoperative knee laxity on 6-year anterior cruciate ligament reconstruction outcomes. Am J Sports Med 
2018;46:2865-72. [CrossRef]

25. Sundemo D, Mikkelsen C, Cristiani R, Forssblad M, Senorski EH, Svantesson E, et al. Contralateral knee hyperextension is associated with increased anterior tibial translation and fewer meniscal injuries in the anterior cruciate ligament-injured knee. Knee Surg Sports Traumatol Arthrosc 2018;26:3020-8. [CrossRef]

26. Larson CM, Bedi A, Dietrich ME, Swaringen JC, Wulf CA, Rowley DM, et al. Generalized hypermobility, knee hyperextension, and outcomes after anterior cruciate ligament reconstruction: Prospective, case-control study with mean 6 years follow-up. Arthroscopy 2017;33:1852-8. [CrossRef]

27. Sonnery-Cottet B, Daggett M, Fayard JM, Ferretti A, Helito CP, Lind $\mathrm{M}$, et al. Anterolateral ligament expert group consensus paper on the management of internal rotation and instability of the anterior cruciate ligament deficient knee.J Orthop Traumatol 2017;18:91-106. [CrossRef]

28. Vadala AP, Iorio R, De Carli A, Bonifazi A, Iorio C, Gatti A, et al. An extra-articular procedure improves the clinical outcome in anterior cruciate ligament reconstruction with hamstrings in female athletes. Int Orthop 2013;37:187-92. [CrossRef]

\section{ORİJiNAL ÇALIŞMA - ÖZ}

\section{Hipermobil hastalarda kombine ön çapraz bağ rekonstruksiyonu ve anterolateral ligament internal breys uygulaması klinik sonuçları etkiler mi? \\ Dr. Mehmet Berkin Toker, ${ }^{1}$ Dr. Tunay Erden, ${ }^{1}$ Dr. Ali Toprak, ${ }^{2}$ Dr. Ömer Faruk Taşer ${ }^{1}$}

${ }^{1}$ Acıbadem Fulya Hastanesi Sporcu Sağlığı Merkezi, Ortopedi ve Travmatoloji Bölümü, İstanbul
${ }^{2}$ Bezmialem Vakıf Üniversitesi Tıp Fakültesi, Biyoistatistik ve Tıp Bilişimi Anabilim Dalı, İstanbul

AMAÇ: Genel eklem hipermobilitesi (GEH), ön çapraz bağ (ÖÇB) yaralanması ve ÖÇB greft yetmezliği için bir risk faktörüdür. Bu hastalarda ÖÇB rekonstrüksiyonuna ilaveten anterolateral ligament rekonstrüksiyonu ya da internal breysi (ALL-iB) önerilmektedir. Bu geriye dönük çalışmanın ama$\mathrm{cı}$, GEH olan hastalarda izole ÖÇB rekonstrüksiyonu ve kombine ÖÇB rekonstrüksiyonu- ALL-IB uygulamasının fonksiyonel sonuçlarını, re-rüptür ve rezidüel instabilite oranlarını karşılaştırmaktır.

GEREÇ VE YÖNTEM: Çalışmaya 20।5-1019 yılları arasında Beighton-Horan kriterlerine göre GEH tanısı konulan ve dahil edilme kriterlerini karşılayan 68 hasta dahil edildi. En az iki yıllık takip süresi bulunmayan hastalar çalışmaya dahil edilmedi. Grup I'de izole ÖÇB rekonstrüksiyonu ve grup 2'de ise kombine ÖÇB rekonstrüksiyonu ve ALL-IB yapılan hastalar yer aldı. Takiplerde hastaların ameliyat öncesi ve sonrası fizik muayene sonuçları ile anteroposterior stabilite (KT-1000) ve diz skorları kaydedildi. Tüm muayene ve ölçümler tek hekim tarafından yapılmıştır.

BULGULAR: Grup I ve 2 sırasıyla 37 ve 3 I hastadan oluşuyordu. Ortalama takip süresi sırasıyla 30 . I \pm 4 . I ve 28 . I \pm 2.9 aydı. Ameliyat sonrası, grup 2 'de yer alan hastaların pivot-shift testi ile daha iyi rotasyonel stabiliteye sahip oldukları görüldü $(p=0.02)$. KT- 1000 artrometri ile yapılan ölçümlerde grup 2'de anteroposterior stabilitenin anlamlı derecede daha iyi olduğu görüldü $(p=0.01)$. Ancak gruplar arasında benzer fonksiyonel sonuçlar (Lysholm için $p=0.14$, Cincinnati için $p=0.1$ I ve IKDC içi $p=0.19)$ ve benzer re-rüptür oranları olduğu görüldü $(p=0.41)$.

TARTIŞMA: Hipermobil hastalarda kombine ÖÇB rekonstrüksiyonu ve ALL-İB daha iyi rotasyonel ve anteroposterior stabilite sağladığı görülmüştür. Ancak daha geniş hasta çalışmaları ve ileriye yönelik randomize kontrollu çalışmalarla tekniğin ve sonuçlarının doğrulanmaya ihtiyacı vardır. Anahtar sözcükler: Anterolateral ligament; augmentasyon; diz instabilitesi; internal brews; ön çapraz bağ rekonstrüksiyonu; sütur tape. 